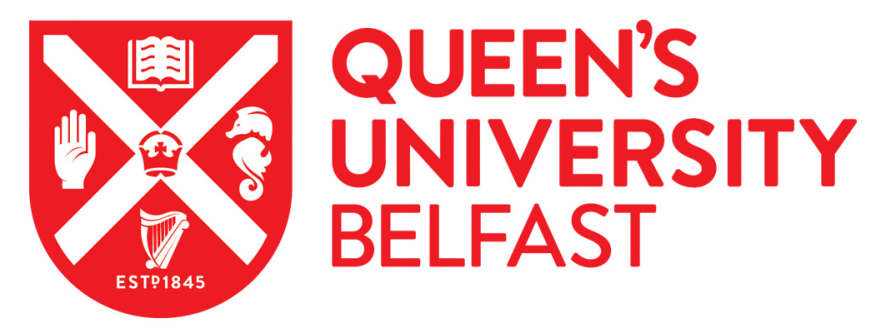

\title{
Balancing Cultural Diversity and Social Cohesion in Education: The Potential of Shared Education in Divided Contexts
}

Loader, R., \& Hughes, J. (2017). Balancing Cultural Diversity and Social Cohesion in Education: The Potential of Shared Education in Divided Contexts. British Journal of Educational Studies, 65(1), 3-25.

https://doi.org/10.1080/00071005.2016.1254156

Published in:

British Journal of Educational Studies

Document Version:

Peer reviewed version

Queen's University Belfast - Research Portal:

Link to publication record in Queen's University Belfast Research Portal

Publisher rights

(C) 2016 Society for Educational Studies

This is an Accepted Manuscript of an article published by Taylor \& Francis in British Journal of Educational Studies on 17 Nov 2016 , available online: http://www.tandfonline.com/doi/full/10.1080/00071005.2016.1254156

\section{General rights}

Copyright for the publications made accessible via the Queen's University Belfast Research Portal is retained by the author(s) and / or other copyright owners and it is a condition of accessing these publications that users recognise and abide by the legal requirements associated with these rights.

Take down policy

The Research Portal is Queen's institutional repository that provides access to Queen's research output. Every effort has been made to ensure that content in the Research Portal does not infringe any person's rights, or applicable UK laws. If you discover content in the Research Portal that you believe breaches copyright or violates any law, please contact openaccess@qub.ac.uk. 


\title{
Balancing cultural diversity and social cohesion in education: \\ The potential of shared education in divided contexts
}

\begin{abstract}
This article considers how the education systems of divided societies have been shaped in response to the experience of ethnic and religious conflict. The analysis identifies two competing priorities in such contexts - the development of social cohesion and the protection of cultural, ethnic and religious identities - and explores how these may be reconciled through a model of 'shared education'. Drawing on research evidence and recent experience of shared education in relation to Northern Ireland, the Former Yugoslav Republic of Macedonia ${ }^{1}$ and Cyprus, we reflect on the advantages and challenges of this model in areas experiencing conflict and division.
\end{abstract}

\section{Introduction}

Across societies that have experienced conflict along ethnic, religious and/or national lines, the structure of the education system reveals diverse responses to resulting social divisions. While some jurisdictions, such as the countries of the former Yugoslavia, largely provide separate schools for different cultural groups, others, like South Africa, have adopted a formal policy of racial desegregation across the education system. This paper critically analyses the educational approaches adopted by a number of divided and conflict-affected societies, focusing on their capacity to promote social cohesion while recognising and respecting difference. The analysis points to significant weaknesses in existing models of education and indicates the need for alternative approaches that can more effectively balance the interests of different cultural groups with the development of social harmony. In this context, the article explores a recent development from Northern Ireland, which has been termed 'shared education'. Introduced in 2007, shared education encourages collaboration between schools across political, religious or ethnic divisions to provide mixed classes and

\footnotetext{
${ }^{1}$ The authors recognise that there is ongoing disagreement between the governments of Macedonia and Greece over the use of 'Republic of Macedonia' as the country's constitutional name (Marusic, 2011; Mavromatidis, 2010). Further, they note that, in the absence of agreement on this matter, the term 'Former Yugoslav Republic of Macedonia' (commonly abbreviated to 'FYR Macedonia’) is preferred by international organisations including the United Nations and European Union. Consistent with this, and with the conventions adopted in respect of Cyprus in this article, the authors employ the terminology of the UN and refer hereafter to 'FYR Macedonia'.
} 
activities for pupils. While schools thus retain their distinct identities and characters, the model of shared education provides regular opportunities for pupils to meet and build relationships over a sustained period. With research demonstrating the positive impact of contact via shared education on pupils' attitudes and behaviours towards opposing groups (Hughes et al, 2010, 2012), this paper reflects on the programme’s potential in other divided societies, drawing on the authors' experience in two settings, Cyprus and FYR Macedonia.

\section{The education system in divided societies}

In divided societies, the structure of the education system commonly reflects different perspectives on the relationship between education, identity and social cohesion. While the provision of separate schooling for different ethnic groups suggests that protecting group cultures and identities is the primary concern, the wholesale desegregation of schools indicates that the promotion of social unity is the greater priority. The first of these approaches, separate schooling along ethnic or religious lines, characterises the education systems of numerous divided societies, including Northern Ireland, where more than 9 in 10 pupils attend schools that are predominantly Catholic or predominantly Protestant (DENI, 2015a); Israel, which operates separate systems for secular Jews, religious Jews, and Palestinians (Bekerman, 2007; Agbaria, Mustafa and Jabareen, 2015); and BosniaHerzegovina and FYR Macedonia, in which pupils from different cultural groups are commonly educated in separate 'shifts' (Lyon, 2013; Tolomelli, 2015). Multiple factors may influence the development of separate education, such as residential segregation, linguistic differences, and the legacy of the involvement of religious bodies in the education system (Lyon, 2013; Johnson, 2007; Smith, 2001). In societies in which minority groups have faced oppression, assimilation or, in extreme cases, the threat of eradication, separate education may also be regarded by minority groups as a means of safeguarding cultural and religious traditions in a potentially hostile environment (Flint, 2007; Gallagher, 2004; Hromadžić, 2008; Weinstein, Freedman and Hughson, 2007).

While the rationale for separate education may be understandable, and its advocates claim that such schools can foster beliefs and values consistent with social cohesion (Grace, 2012; Halstead and McLaughlin, 2005), others have argued that separate schools risk perpetuating and entrenching social division (Berkeley, 2008; Cantle, 2001). The crux of the arguments advanced by Berkeley and Cantle is that a lack of intercultural contact in monoethnic or monoreligious schools can result in ignorance, prejudice and the entrenchment of 
segregation. Recent research from Northern Ireland appears to give some credence to these concerns. This has found that, compared with pupils attending the region's small number of integrated schools (i.e. those which educate children from Catholic, Protestant and other backgrounds together, maintaining a religiously balanced enrolment), pupils who attend separate schools report less positive attitudes towards the other group, more polarised positions on politics and national identity, and a poorer understanding of the other group's culture and religion (Hughes et al., 2013; Hayes, McAllister and Dowds, 2007, 2013; Stringer et al., 2000, 2009). Statistical analysis by Hughes et al. (2013) and Stringer et al. (2009) has attributed this divergence to differences in the quality and frequency of contact experienced by pupils attending separate schools and those enrolled in integrated schools.

The aim of integrated education in societies affected by conflict has been to provide an alternative to separate schools in which "children who are more normally educated apart are deliberately educated together” (Bekerman and Zembylas, 2013, p.xi). The development of integrated education has been most extensive in Northern Ireland, arguably due to the lower intensity violence and the use of English as the primary language of both groups, but there also exist a small number of integrated bilingual schools in Israel. In Northern Ireland, the first integrated school was founded in 1981 by a group of concerned parents with support from philanthropic and charitable organisations (Fraser and Morgan, 1999). Since then, the sector has grown to its current size of 65 schools (45 primary and 20 post-primary schools), which receive full government funding, educate just under 7 per cent of the region's pupils and are explicitly Christian in character (DENI, 2015; Meredith, 2016; Northern Ireland Council for Integrated Education, 2016). In Israel, the integrated sector has developed more slowly: the first bilingual school was established in 1984 by members of a small binational community, and five subsequent schools were founded between 1998 and 2013 by the Centre for Jewish-Arab Education (Bekerman, 2007; Centre for Jewish-Arab Education, 2015; Donnelly and Hughes, 2006). These schools are designated as non-religious and use the standard curriculum of non-religious schools, but classes (usually) comprise equal numbers of Arab and Jewish students and are taught by two teachers, one Arab and one Jewish, using both Arabic and Hebrew as the languages of instruction (Bekerman, 2007; Zembylas et al, 2009).

Integrated schools in Northern Ireland and integrated bilingual schools in Israel have attracted substantial attention from researchers. As outlined above, survey studies in Northern Ireland 
have pointed to the positive impact of these schools on pupils' attitudes towards the other group (Hughes et al., 2013; Stringer et al., 2009), while studies from Israel have reported favourable outcomes such as reduced social distance and the development of more fluid and complex cultural identities among students (Bekerman, Habib and Shhadi, 2011; Ben-Nun, 2013). At the same time, this research highlights a number of challenges facing such schools. These include combining high-quality education with the achievement of reconciliation aims (Donnelly and Hughes, 2006; McGlynn and Bekerman, 2007); negotiating competing visions of integrated/bilingual education among staff and parents (Bekerman and Horencyk, 2004; McGlynn, 2007; McGlynn and Bekerman, 2007; Montgomery et al., 2003); and promoting friendship, equality and mutual respect in a societal context in which intergroup hostility and inequality are pervasive (Bekerman and Horencyk 2004; Bekerman, 2007; McGlynn et al., 2004). Schools in both jurisdictions have also received criticism (albeit of a different nature in each case) for their response to the cultural diversity within their intakes. While research suggests that bilcultural schools in Israel have tended to essentialise and reify cultural differences (Bekerman, 2007; Ben-Nun, 2013), integrated schools in Northern Ireland have been criticised for their inattention to difference and consequent neglect of opportunities to challenge prejudice and develop respect for diversity(Donnelly, 2004, 2008; Ben-Nun, 2013).

While integrated schools in these contexts exist as alternatives to separate education, other societies have responded to division with a policy of more comprehensive desegregation. In recent decades, this has been the approach adopted by the government of post-apartheid South Africa, which opened up formerly segregated schools to students from all racial backgrounds as part of its policy to address educational inequalities (Soudien, 2007; Zembylas et al., 2009). This has resulted in significant demographic change across schools, although the pattern of migration is complex. While most movement has been into former white schools, black pupils appear to have moved as frequently into former Indian and coloured schools, and there has been no movement into former black schools (Chisholm and Sujee, 2006; Soudien, 2004). Although these changes have led to greater 'mixing', integration continues to be circumscribed by national demographics, residential segregation, and social background (with some former white schools charging fees) (Soudien, 2007; Zembylas et al, 2009). It is projected, for example, that 75 per cent of schools will continue to be attended almost exclusively by black students (Soudien, 2004). 
Although the intention in desegregated schools is to foster integration and equality among pupils in a common school environment, research from South Africa has questioned the extent to which this aim has been realised. In particular, concerns have been expressed that, while some schools have adopted an explicitly multicultural ethos in response to their more mixed student body, the prevailing approach in newly mixed schools is assimilationist (Soudien, 2004; Vandeyar, 2010). In these schools, pupils from diverse cultural backgrounds are encouraged - either tacitly or overtly - to adopt the cultural values and practices of the dominant group within the school (Soudien, 2004; Vandeyar and Esakov, 2007). This approach is reinforced by the tendency of newly mixed schools to retain a monocultural teaching staff and to deliver instruction in only one or two languages, most commonly English, despite political support for multilingualism via the 1997 Language in Education Policy (Bray and Joubert, 2007; Vandeyar and Esakov, 2007; Zembylas et al, 2009). As Vandeyar and Killen (2006, p.387) comment, “instead of becoming models of societal integration...schools have continued to reflect the hegemonic dominance of whiteness that characterized pre-apartheid schooling”.

\section{Shared education}

Against this background, a new educational approach, termed 'shared education', has been implemented in Northern Ireland since 2007. Operating within the region’s parallel education system, shared education was introduced as a means of fostering collaborative partnerships between schools across religious, cultural and political divisions. These partnerships permit the sharing of resources, the joint provision of professional development opportunities for staff, and the delivery of curriculum-based classes to mixed groups of pupils, who travel between the schools to attend lessons. Through this model of school collaboration, shared education can facilitate regular contact between students without the need for structural change to the education system: while parents retain the option of faith-based education for their child, shared education creates frequent opportunities for pupils across separate schools to interact and learn together. By linking contact to the delivery of the curriculum, shared education also helps to embed reconciliation in schools' core activities, ensuring that it cannot be overlooked as an 'add-on' or optional element as has been the case in the past (Borooah and Knox, 2013; Hughes, 2014; Hughes et al., 2010).

As the last point suggests, the development of shared education builds on learning from previous initiatives to enhance community relations through education. For example, school 
partnerships are encouraged to plan activities around their schools' priorities and deliver these over a sustained period to avoid emulating the short-term, low-impact programmes of the past (Gallagher, 2004; Hughes, 2014; Richardson, 2011). The programme’s architects have also sought to embed shared education within the contemporary policy environment. The model of collaboration is consistent with a policy drive to encourage cooperative working between schools as a mean of extending educational opportunities and fulfilling the legal requirement to offer a minimum number of subjects at ages 14 and 16 (Gallagher, 2016; Knox, 2010). Similarly, shared education offers the possibility of financial savings through the pooling of schools' resources, thereby helping to reduce the additional costs associated with a divided education system (Borooah and Knox, 2013).

As well as drawing on past experience, the development of shared education has been informed by a diverse theoretical literature. This includes theory and research on communities of practice (Wenger, 1998, 2000), particularly concerning the development of porous boundaries between institutions and the use of 'bridging' to connect people and share knowledge (Gallagher, 2016); social network theory and the value of 'weak ties' as a source of information and learning (Granovetter, 1973); and intergroup contact theory (Allport, 1954; Pettigrew and Tropp. 2006). The latter, which is embedded in the reconciliation dimension of shared education, posits that contact with a member of a negatively stereotyped group will lead to a reduction in prejudice towards that group as a whole, particularly where four facilitating conditions are present: cooperation, common goals, equality between participants, and institutional support (Allport, 1954). A large body of research provides empirical support for this hypothesis and has identified processes which help to promote more positive intergroup attitudes, including a reduction in anxiety and improved ability to empathise with the outgroup (Pettigrew and Tropp, 2006, 2008). The association of these processes with more established and intimate relationships informs the emphasis on sustainability within the shared education model (Hughes and Loader, 2015).

From 2007 until 2013, shared education was delivered primarily through three programmes funded by Atlantic Philanthropies and the International Fund for Ireland: the Primary Integrating and Enriching Education Project (PIEE), delivered by the North Eastern Education and Library Board; the Shared Education Programme, coordinated by the Fermanagh Trust for primary and post-primary schools in Fermanagh; and the Sharing Education Programme (SEP), which was managed by Queen’s University and operated 
across Northern Ireland, principally with post-primary schools. The latter involved 150 schools and more than 15,000 pupils across two cohorts (2007-2010 and 2010-2013) (Knox, 2013). Reflecting the interest in these initiatives among policymakers, a commitment to develop and extend shared education was included in the Northern Ireland Executive's Programme for Government 2011-2015 (Northern Ireland Executive, 2011).

Following the conclusion of the initial tranche of funding in 2013, Atlantic Philanthropies and the Northern Ireland Executive announced a joint commitment of $£ 58$ million for three flagship programmes, including shared education (Atlantic Philanthropies, 2014). This funding is available from 2015 for four years through the Shared Education Signature Project, which is managed by the Department of Education (DENI, 2014). To support such initiatives, the Northern Ireland Executive also introduced the Shared Education Act (Northern Ireland), which took effect in May 2016 and confers a duty on the Department of Education (NI) to encourage, facilitate and promote Shared Education. Notably, this Act defines shared education as encompassing the cooperation of two or more providers to educate together '(a) those of different religious belief, including reasonable numbers of both Protestant and Roman Catholic children or young persons; and b) those who are experiencing socioeconomic deprivation and those who are not' (Shared Education Act 2016, emphasis added). This allows the possibility of 'sharing' between providers of the same denomination, providing they cater for young people from contrasting socio-economic backgrounds.

Research into shared education has largely been undertaken in school partnerships affiliated to the Sharing Education Programme (SEP) at Queen’s University and has identified generally positive outcomes of participation. Compared with pupils enrolled at schools that are not involved in shared education, pupils attending participating schools typically report a higher number of friends from the other group, lower levels of anxiety regarding cross-group interaction, and more positive attitudes towards the other (Hughes et al., 2010, 2012). Students at participating schools also demonstrate more positive action tendencies - that is, the desire to help, support, and learn more about the other community (Hughes et al., 2010, 2012). Importantly, those attending SEP schools in divided areas reported more favourable intergroup attitudes than pupils at non-participating schools in areas characterised by more harmonious relations (Hughes et al., 2010). Research also suggests that the effects of shared education extend beyond direct participants. Interviews with students have found that, particularly in less divided areas, non-participating pupils have forged cross-group 
friendships through friends who are involved in the programme (Hughes, 2014; Hughes et al., 2010). Moreover, research with staff has indicated that inter-school collaboration has a 'ripple effect' within the wider community, both directly, via the provision of joint events for parents and others, and indirectly, by acting as a model of positive and cooperative relations (Knox, 2010; Hughes, 2014).

While these findings are encouraging, research into SEP has also highlighted a number of teething problems. From a logistical perspective, teachers and school managers have commonly recounted difficulties coordinating timetables, managing transport arrangements, and negotiating diverging school policies and processes, particularly during the early stages of implementation (Gallagher, 2016; Gallagher et al., 2010; Knox, 2010). Despite these issues, teachers have reported that they value shared education for the opportunities that it offers to develop new professional relationships and to share ideas and expertise (FGS McClure Watters, 2014; Knox, 2010). Most of those involved in SEP also spoke of wishing to continue with the programme once their funding expired, but acknowledged the challenges of sustaining shared education with fewer resources (Duffy and Gallagher, 2014; Knox, 2010). In the Northern Ireland context, these challenges have been exacerbated by a wider policy context that has historically provided few incentives for inter-sectoral collaboration (Hughes et al., 2012), although the announcement of government funding for shared education in 2015 has gone some way towards addressing this.

Two further issues merit additional attention if the programme is to achieve maximum impact. The first is the fact that a minority of pupils (approximately 10\%) report negative experiences of contact through shared education (Gallagher et al., 2010). While survey data does not elaborate on the reasons for this, it may be partially explained by findings from qualitative research that some pupils encounter intimidating behaviour and name-calling from non-participating students when attending partner schools (Hughes et al., 2010; Loader, 2015). Further research may be valuable in understanding the impact of these encounters on pupils and developing appropriate responses. Second, qualitative research indicates that pupils and teachers involved in shared education remain nervous about discussing issues related to difference in mixed classes and prefer to avoid these topics or discuss only the least contentious (Loader and Hughes, 2016). While the absence of any requirement to explore difference via shared education may help participants to feel comfortable in the early stages, ongoing avoidance of these issues might reduce opportunities to build trust, deconstruct 
stereotypes and critically examine questions of identity and social justice (Donnelly, 2012; Loader and Hughes, 2016). If shared education is to address these issues directly, more explicit aims and guidance may be required.

\section{Shared education in other divided contexts}

In view of the generally promising findings emerging from research on SEP in Northern Ireland, shared education has begun to attract attention from researchers and policymakers from other jurisdictions seeking lessons for their own education systems. In the following sections, this article explores the relevance and potential of shared education in two countries, FYR Macedonia and Cyprus, where programmes are at different stages of development. With separate education a feature of both regions, and integrated schools being locally unfeasible or undesirable, shared education can offer a means of bringing pupils from different backgrounds together within the constraints of the respective education systems. The nature of the programme and its prospects of success in each country are, however, shaped by contextual factors such as the political mood, the organisation of education, the design of the curriculum, and the local demographics. Recognising the importance of contextual understanding to any discussion of policy 'lending’ (Beech, 2006; Phillips and Ochs, 2003; Steiner-Khamsi, 2014), these sections draw on our experiences of developing shared education in each country to explore the (potential) benefits of the model in international contexts and identify facilitators and barriers to implementation. While research in both jurisdictions is ongoing, this analysis permits an assessment of shared education's application in other divided societies.

\section{Shared education in the Former Yugoslav Republic of Macedonia}

FYR Macedonia is located in south-east Europe, on the Balkan Peninsula, sharing a border with Albania, Bulgaria, Greece, Kosovo and Serbia. Its population of approximately 2.1 million is composed of two principal groups, ethnic Macedonians (64.2\%) who are concentrated in urban areas, and ethnic Albanians (25.2\%), who reside principally in Skopje and in the rural regions in the west of the country; other groups, including Turkish (3.9\%), Roma (1.9\%) and Serbian (1.2\%), also comprise notable populations (CIA, 2016; Koppa, 2001; Johansen and O’Neill, 2012). Since gaining independence in 1991, FYR Macedonia has been the site of ongoing tensions stemming largely from Albanian anger at what they perceive as oppression by the Macedonian-dominated state (Koppa, 2001; Reka, 2008). These tensions reached a peak in the spring and summer of 2001, when ethnic Albanians 
staged an uprising, seizing and occupying territory in the north-west of the country (Koneska, 2012; Koppa, 2001; Reka, 2008). The civil war that this threatened was averted following a process of negotiation, overseen by international actors including the EU and USA, which resulted in a framework agreement signed by the leaders of the Macedonian government and major Albanian political parties in August 2001. While this has resulted in greater stability, tensions in FYR Macedonia persist, erupting most recently in Kumanovo in May 2015 with the loss of 22 lives (BBC, 2015; The Guardian, 2015).

In line with the first of the previously discussed approaches to organising education in divided societies, FYR Macedonia is characterised by a largely separate education system. A key factor in this separation has been the extension of education in non-majority languages (that is, languages other than Macedonian, most commonly Albian, but also including Serbian and Turkish). While provision for mother tongue education at primary and secondary level was included in Article 48 of the 1991 constitution, it became more widespread with the decentralisation of education from 2005, particularly at primary level (Azizi, 2011; Lyon, 2013). This has resulted in greater ethnic segregation in schools and classrooms as pupils and families seek education in their first language (Lyon, 2013). Against a background of division, this increasing ethnic concentration has provoked concern both within government and among commentators on education, who have called for strategies to promote greater integration (Johansen and O’Neill, 2012; Lyon, 2013; Ministry of Education and Science, 2010; Reka, 2008). However, as the government's 2010 integration strategy recognises, such approaches must balance opportunities for inter-ethnic contact with respect for mother tongue instruction (Ministry of Education and Science, 2010). Any perceived threat to the latter, which is considered good practice from a minority rights perspective (Lyon, 2013), is likely to be viewed as regressive and strongly resisted.

Recognising the potential of shared education in FYR Macedonia, NGOs active in education in the region approached staff in the School of Education at Queen's University, Belfast, in 2010/11 to request their assistance in identifying how principles of the programme in Northern Ireland could be applied locally. In the context of FYR Macedonia, shared education offers a number of advantages. Firstly, an important feature of the model is its acknowledgement of parents' rights to select a particular education for their child (Hughes and Loader, 2015), including education in the home language. Rather than require the curtailment of these rights, shared education provides the framework for pupils at separate 
schools to meet on a regular basis for bilingual instruction. In this respect, the model is consistent with the Macedonian government's vision of “integration through joint activities involving students receiving tuition in different languages... within schools and between different schools” (Ministry of Education and Science, 2010, p.3). Secondly, the opportunity for schools to share materials and facilities is valuable in a setting like FYR Macedonia, where resources in education are often stretched and institutions have very limited funding. Where schools have been able to secure external investment for sports or science facilities, partnership through shared education enables pupils and teachers at other, less well-resourced institutions to avail of these facilities, thereby enhancing their educational experience and ensuring greater equality across local provision.

A third advantage of shared education is its potential to develop at a rate appropriate to the local context. While the promotion of integration through common schooling requires communities to accept the merging of schools as the eventual aim, shared education adopts no similar goals and no deadlines. Instead, school partnerships are permitted to evolve as slowly or quickly as the local circumstances permit. This is particularly important in divided societies such as FYR Macedonia, in which the nature of relations and attitudes towards peacebuilding can vary between areas and communities. Tailoring both the activities and the expectations of each partnership to the local area, as has happened in shared education initiatives in Northern Ireland, helps to build support - and reduce resistance - by ensuring that programmes do not push "too far ahead of the more entrenched attitudes" (Knox, 2010, p.16). Moreover, in societies like FYR Macedonia, where there remain tensions around religious and cultural difference, the 'backgrounding' of reconciliation objectives in shared education can be helpful in securing the support and trust of both participants and staff, particularly during the early stages (Hughes, Leitch and Baker, 2011).

Work in FYR Macedonia to date has also identified a number of features of the education system that are amenable to shared education. From a structural perspective, the involvement of NGOs in education in the region (Murchan et al., 2012), together with the decentralisation of educational administration, has created a favourable environment for the introduction of local pilot initiatives. Within this context, the role of UNICEF and USAID in sponsoring project has proved valuable, not only in providing funding and resources, but also in contributing knowledge of the local educational landscape and facilitating access to schools and teachers. The existence of a common school curriculum has also greatly assisted shared 
education in FYR Macedonia. As all schools follow a common curriculum irrespective of their language of instruction (Hughes, Leitch and Baker, 2011; Murchan et al., 2012), the task of identifying subjects and activities to be delivered via shared education is relatively straightforward. In the development of shared education, favoured subjects have included those requiring less verbal instruction, such as music, art and dance, which are delivered in shared classes taught jointly by Macedonian- and Albanian-speaking teachers. Over time, as teachers become more confident and trust in the programme increases, this model of bilingual instruction may be adapted to other subjects.

While these features have benefited shared education in FYR Macedonia, a number of administrative and logistical issues have proved more challenging to negotiate. Geographical divisions in the country are one such issue, limiting the potential for face-to-face contact to municipalities with some level of ethnic diversity and to schools within travelling distance of potential partner institutions. Such difficulties face all integration projects, however, and the flexibility of shared education is arguably advantageous, allowing schools to schedule joint sessions at their convenience and potentially to introduce online sessions (via internet conferencing) where technology allows. The persistence of 'shift' systems, which schools operate as a way of managing a lack of building capacity (Koneska, 2012; Lyon, 2013; Murchan et al., 2012), also remains a barrier to shared education between or within institutions operating on the same site. Commonly organised along ethnic and religious lines, these shifts impede opportunities for contact between students who attend different schools. Although the reform of the shift system is dependent on the wholesale reorganisation of the schools estate, proposed interim strategies have included adjusting the timing of shifts to provide an 'overlap' period in which shared activities can be scheduled (Hughes, Leitch and Baker, 2011).

Third, while all schools prepare pupils for either State Matura or School Matura exams (Murchan et al., 2012), the non-standardised nature of the School Matura has presented some challenge. As the assessments for this examination are conducted at school level, there have been difficulties in allowing assessment undertaken at other schools to be counted towards a student's final qualification (Hughes, Leitch and Baker, 2011). Legislative change is required to ensure that courses completed at a partner institution can count towards the pupil's final result. Finally, and more relevant at secondary level, perceived differences in the standards of Albanian and Macedonian schools (Reka, 2008) have aroused some concerns among parents, 
staff and others about parity in the quality of education received by participants of shared education. As work undertaken in Northern Ireland has highlighted, shared education is likely to have the greatest success where it is accompanied by initiatives to promote quality and reduce inequity across all sectors (Connolly, Purvis and O’Grady, 2013).

\section{$\underline{\text { Shared education in Cyprus }}$}

The partition of Cyprus dates from 1974, when Turkey deployed troops on the island in response to an attempted coup by Greek Cypriot nationalists to bring about the unification of Cyprus and Greece (Oztas et al., 2016; Papadakis, 2008). In the conflict that followed, approximately 200,000 Greek Cypriots were displaced to the south of the island and 45,000 Turkish Cypriots to the north, with a UN-patrolled Buffer Zone (the 'Green Line') separating the two parts (Johnson, 2007; Papdakis, 2008; Zembylas et al., 2011a). Although a separate state was unilaterally declared in the north of the island in 1983, the international community (with the exception of Turkey) recognises only the government of the Republic of Cyprus and considers northern Cyprus to be under illegal occupation by Turkey (Shaw, 2014; Zembylas et al., 2011a). Movement between the two parts was not possible until April 2003, when border restrictions were relaxed and checkpoints opened (Johnson, 2007). This significant development was followed a year later by a referendum on the unification of Cyprus as a federal state: though supported by a majority (65\%) of Turkish Cypriots, less than a quarter (24\%) of Greek Cypriots voted in favour (Philippou, 2007; Zembylas et al., 2011a). After a period of hiatus, peace talks resumed in 2015 and were ongoing at the time of writing (Foster, 2016; Tugwell and Georgio, 2016).

Education in the Cyprus prior to partition was organised and managed along communal lines (Silman and Caglar, 2010; Hajosoteriou et al., 2012). With the division of the island, the two systems developed entirely independently. Both forged a strongly nationalistic character, characterised by the celebration of their community's culture and heritage, the commemoration of the actions of their 'side' in the conflict, and the denigration of the other in textbooks and the curriculum (Papadakis, 2008; Zembylas et al., 2011a). Although elements of nationalism and ethnocentrism continue in education today, the opening of checkpoints, the election of pro-solution parties on both sides, and, in the Republic of Cyprus, the requirements of EU accession precipitated the development of more inclusive curricula and resources (Charalambous et al., 2014; Hajisoteriou et al., 2012; Papadakis, 2008; Philippou, 2007). Despite these developments, there remain few opportunities for young 
people in Cyprus to be educated together. The geographical separation of the island has rendered integrated schools largely impracticable (with the exception of several privately funded international schools, located in the south of the island (Zembylas, 2010)), while the 'non-recognition’ policy of the Republic of Cyprus towards the north has limited opportunities for collaboration across the Green Line.

Following shared education's success in Northern Ireland and the emerging interest in its approach elsewhere, Queen's University was awarded funding by Atlantic Philanthropies in 2014 for the development of shared education programmes in other divided societies. Cyprus was selected as a potentially appropriate site for several reasons. Firstly, the fact that shared education can proceed without structural change to education was deemed important: with no change to educational arrangements likely in the short term in Cyprus, shared education appeared the most feasible approach to increasing integration across the two separate systems. Secondly, the ease of adapting shared education and initiating programmes on a small scale was considered an asset in such a politically sensitive context. With concerns over security and political recognition likely to restrict the movement of students, programmes could begin by involving only teachers in shared activities, as outlined below. A further advantage of Cyprus was the potential to work with local colleagues, who could contribute valuable contextual insights and previous experience of reconciliation work in the region.

Recent developments in Cyprus also appear propitious for shared education. One such development has been the increased collaboration between the major Greek Cypriot and Turkish Cypriot teaching unions. This was initiated in January 2015 with an agreement to cooperate, signed by six teaching unions, three Greek Cypriot and three Turkish Cypriot, representing primary, secondary and tertiary education (ETUCE, 2015); a joint press conference and teachers' conference followed in October 2015 and January 2016 respectively (Independent Balkan News Agency, 2015; ETUCE, 2016). While these relationships remain cautious, this greater cooperation is promising in view of the strength of the unions on the island, their receptiveness to peacebuilding initiatives (including shared education), and their combined experience of facilitating bicommunal/bilingual (Greek-speaking and Turkishspeaking) initiatives. A second favourable development has been the creation of the Bicommunal Committee on Education, which was established in November 2015 with a remit to review and conduct research on the contribution of education to reconciliation and importantly for shared education - to facilitate “contact and cooperation between students 
and educators from the two communities” (United Nations Security Council, 2016, p.2). The 22-member Committee held its first meeting in February 2016 and was due to deliver its first report in September of the same year (Kades, 2016).

As in FYR Macedonia, however, the introduction of shared education in Cyprus is likely to encounter a number of obstacles, three of which merit particular consideration here. With peace talks ongoing, the first of these obstacles - the lack of a political settlement - may be resolved in the near future, but in current circumstances presents both administrative and logistical challenges. While the border is a significant logistical barrier to face-to-face contact, political concerns may also reduce possibilities for shared education, even among those living close to the Green Line. Given the sensitivities surrounding the recognition of a northern state, the government of the Republic of Cyprus and some sections of the public are unlikely to sanction staff and/or student travel into the occupied territory. As movement between schools has been a key element of shared education in Northern Ireland, this raises questions about how to retain the integrity of the model as it moves into the new context. To adapt to the circumstances of Cyprus, we have proposed an approach involving the delivery of joint activities, including training and professional development opportunities, to partnerships of Greek Cypriot and Turkish Cypriot teachers in the UN Buffer Zone. If organised on the same basis as previous shared education programme - e.g. adopting a school partnership model, focusing on shared educational and pedagogical concerns, and emphasising sustainability - such a programme would achieve an acceptable balance between retaining the distinctive features of shared education and adapting to local exigencies. Over time, these principles could be applied to a model of online contact between students across the island, with face-to-face contact a more long-term aspiration, contingent on political developments.

While shared education's ability to work across Cyprus's separate education systems is one of the programme’s strengths, doing so also presents a series of challenges. For one thing, differences in the structure of each system can make joint working more complex: for example, whereas the primary phase of education begins at age 5 in the Republic of Cyprus, children in the northern part of the island start primary school at the age of 7 (Europa, 2003; Ministry of Education and Culture, 2016). Collaborative activities for teachers working in early primary education must therefore reflect these differences. Similarly, the existence of separate curricula and examination regimes makes it more challenging to identify a shared 
curricular focus for joint training and activities. Pragmatically, a lack of alignment between the two curricula means that, even for those teaching pupils of the same age, the curriculum requirements and targets are likely to differ. Moreover, despite significant reform over the past decade, ethnocentric and nationalistic elements persist within the curriculum and textbooks in each case, particularly in subjects like history and citizenship (Charalambous, Charalambous and Zembylas, 2014; Hajisoteriou and Angelides, 2013; Papadakis, 2008; Vural and Ozuyank, 2008), complicating sharing in these areas.

Cognisant of these challenges, proposals for shared education in Cyprus include joint training for staff on issues of common interest among those working with young people - such as online safety and health and relationships (see Duffy and Gallagher, 2016, for a similar example from Northern Ireland) - as well on the specific issues associated with teaching in divided contexts. The latter includes training on dealing with controversial and sensitive issues in the school context, which has relevance beyond shared education and encourages teachers to reflect on their own identities and values, as well as explore appropriate pedagogies. Also included is more programme-specific training on developing collaboration across key curriculum areas, including art and music. As in FYR Macedonia, these subjects appear particularly suitable for shared education in Cyprus - where Greek Cypriots and Turkish Cypriots speak different languages - as they require less extensive verbal instruction. Moreover, in the context of separate curricula, there is considerable scope in these subject areas to develop shared activities that are both educationally relevant and politically acceptable.

Proposals for training on addressing contentious issues at school level anticipate a third potential challenge facing shared education in Cyprus, which relates to the nature of intercommunal relations in the region and shared education's capacity to respond to such division. While there have been positive developments in recent years, there remains in some quarters considerable ambivalence towards reconciliation and antipathy towards the other group (Ioannou et al, 2015; Zembylas, 2010; Zembylas et al., 2011b). To address these attitudes in the context of education, Zembylas (2010, p.450) emphasises the need for schools to move towards a more critical approach that encourages individuals to examine "the construction of identities and social structures” as a step towards transforming social relations. As discussed above, however, previous research on shared education in Northern Ireland has suggested that the lack of an explicit aim to explore difference, and a 
corresponding tendency towards avoidance on the part of teachers and students, impedes the programme's capacity to explore and critique issues of identity and inequality (Hughes and Loader, 2015; Loader and Hughes, 2016). The challenge, then, for shared education programmes in Cyprus (and in FYR Macedonia, Northern Ireland and elsewhere) is to create an environment in which participants can explore these difficult issues sensitively and constructively, leading to genuine social change.

\section{Conclusion}

Across plural societies, and particularly in those that have experienced ethnic conflict and division, the education system faces the challenge of balancing the rights and interests of diverse cultural groups with the promotion of social unity. Existing models of separate and common schooling, reviewed herein, tend to require compromise, safeguarding identity at the cost of integration, and vice versa. As an intermediary between these approaches, shared education aims to provide opportunities for frequent sustained contact without requiring schools to give up their distinctive identity and ethos. The foregoing discussion of shared education in Northern Ireland, Cyprus and FYR Macedonia has highlighted a number of advantages of this model in divided societies, including its capacity to promote greater integration within education in situations where alternative approaches (such as integrated schools) may be unfeasible or undesirable. In this regard, shared education's flexibility to work across distinct educational systems and separate curricula is a clear benefit. So, too, is its acceptance of sustained 'sharing' as an end in itself, rather than a precursor to fully integrated schooling. This ensures that the model is appropriate to countries where separate (mother tongue) education is considered important for protecting minority rights and cultures, like FYR Macedonia (Lyon, 2013), as well as those where attitudes towards separate education have been more ambivalent, such as Northern Ireland (Gallagher, 2004; Hughes, 2011).

The review of shared education in this paper highlights further advantages of the model for divided societies. Important in each of the three countries discussed is the ability to tailor the organisation and delivery of shared education to the context in which it operates. This enables schools to develop their partnerships at a pace appropriate to the local circumstances and dynamics, helping programmes to build support among teachers, parents and the local community. Adapting individual programmes to the local context also allows shared activities to be organised around the educational priorities of partner schools, thereby 
providing an incentive for involvement and a set of shared goals to unite participants from different institutions. An additional benefit of shared education in divided societies is the opportunity to share resources between schools, often in circumstances where facilities are limited. While this is perhaps most relevant in FYR Macedonia, it has also proved important in Northern Ireland, where shared education has enabled schools to access facilities and deliver courses - particularly, Knox (2010) argues, for less academically able pupils - which they could not afford to do alone. Sharing resources in this way can enhance the educational opportunities available to pupils and, importantly in areas characterised by division, mitigate feelings of injustice provoked by the perception that resources are unequally distributed.

While presenting a number of benefits of shared education in divided societies, this comparative analysis has also identified several challenges facing the programme. One such challenge relates to the timing of shared education and its fit with the policy environment in the relevant country, which our experience has highlighted as important to its success. In Northern Ireland, shared education garnered support because it accorded with the contemporary policy emphasis on collaboration and resource-sharing between schools; in FYR Macedonia, shared education could gain traction, in part, because its approach was consistent with the government's vision for integration in the region; and in Cyprus, the prospects for shared education have been enhanced by recent developments in support of the wider peace process on the island, such increased cooperation between teaching unions and the creation of a Bicommunal Technical Committee on Education. In contexts where these synergies are less evident, or where the policy environment changes, the introduction of shared education may prove difficult. Even where there are clear consistencies between shared education and local policy priorities, programmes must also navigate practical and logistical issues - such as the existence of different curricula and conflicting examination arrangements - which can render implementation more complex.

A further challenge concerns shared education's capacity to address issues of difference in divided societies. Central to the programme's appeal for schools, as we have highlighted, is its focus on educational and economic outcomes and its de-emphasis of reconciliation objectives in comparison to previous peace education initiatives. While this is important in building support for schools' participation, there is a risk that, over time, reconciliation aims may again be deprioritised and matters of identity, conflict and injustice will remain unaddressed. This appears to have been the case in Northern Ireland to date, and our 
experiences in FYR Macedonia and Cyprus suggest that a similar outcome may be likely. The concern in such instances is that, rather than taking the opportunity to challenge narratives and structures that perpetuate inequality, shared education will serve only to facilitate contact within the existing framework of intergroup relations. As shared education develops in new contexts, it is imperative that those involved in these programmes consider how diversity can be sensitively and appropriately addressed within each setting, ensuring that opportunities to explore differences of identity and experience are not lost.

When educational programmes developed in one context are transferred to other locations, it is crucial that those involved in their design and delivery understand the contextual dynamics of the new setting and their impact on implementation (Phillips and Ochs, 2003; SteinerKhamsi, 2014). In elucidating the challenges and opportunities facing shared education in FYR Macedonia and Cyprus, this discussion has sought both to explore the relevance of the shared model beyond Northern Ireland and to provide grounded insight into the factors likely to shape its implementation in other conflict-affected regions. As we continue to develop shared education in these and other settings, an ongoing programme of research will allow us to examine further the operation of shared education, as well as explore its impact on educational practice and participants' intergroup attitudes and behaviours. Collectively, this work seeks to enhance our understanding of shared education's contribution to education in divided societies, which face the challenge of balancing the protection of cultural diversity with the exigencies of social cohesion.

\section{References}

Agbaria, A.K., Mustafa, M. and Jabareen, Y.T. (2015) “"In your face” democracy: education for belonging and its challenges in Israel', British Educational Research Journal 41(1), pp.143-175.

Allport, G.W. (1954) The nature of prejudice. Reading, MA: Addison-Wesley. 
Atlantic Philanthropies (2014) Robinson and McGuinness announce £58 million investment [online]. Available at: http://www.atlanticphilanthropies.org/news/robinson-and-mcguinnessannounce-58-million-investment (Accessed: 4 October 2016).

Azizi, A. (2011) 'The right to education in the Republic of Macedonia: the right to education in one’s mother tongue', Procedia - Social and Behavioural Sciences, 15, pp.2435-2440.

BBC (2015) Macedonia blames Kosovans for deadly Kumanovo clashes [online]. London: BBC. Available at: http://www.bbc.co.uk/news/world-europe-32680904 (Accessed 3 September 2016).

Beech, J. (2006) 'The theme of educational transfer in comparative education: a view over time’ Research in Comparative and International Education, 1 (1), pp.2-13.

Bekerman, Z. (2007) 'Developing Palestinian-Jewish bilingual integrated education in Israel: opportunities and challenges for peace education in conflict societies', in Bekerman, Z. and McGlynn, C. (eds.) Addressing ethnic conflict through peace education, Basingstoke: Palgrave Macmillan, pp.91-106.

Bekerman, Z. and Horenczyk, G. (2004) 'Arab-Jewish Bilingual Coeducation in Israel: a long-term approach to intergroup conflict resolution', Journal of Social Issues, 60(2), pp.389404.

Bekerman, Z. and Zembylas, M. (2011) 'General introduction: interrogating the meaning(s) and doing(s) of “integrated education”'. In McGlynn, C., Zembylas, M. and Bekerman, Z. (eds.) Integrated education in conflicted societies. Basingstoke: Palgrave Macmillan.

Bekerman, Z., Habib, A. and Shhadi, N. (2011) 'Jewish-Palestinian integrated education in Israel and its potential influence on national and/or ethnic Identities and intergroup relations', Journal of Ethnic and Migration Studies, 37(3), p.389-405.

Ben-Nun, M. (2013) 'The 3Rs of integration: respect, recognition and reconciliation; concepts and practices of integrated schools in Israel and Northern Ireland', Journal of Peace Education, 10(1), pp.1-20. 
Berkeley, R. (2008) Right to divide? Faith schools and community cohesion. London: Runnymede Trust.

Borooah, V.K. and Knox, C. (2013) 'The contribution of "shared education” to CatholicProtestant reconciliation in Northern Ireland: a third way?’ British Educational Research Journal, 39(5), pp.925-946.

Bray, E. and Joubert, R. (2007) 'Reconciliation and peace in education in South Africa: the constitutional framework and practical manifestation in school education’, in Bekerman, Z. and McGlynn, C. (eds.) Addressing ethnic conflict through peace education, Basingstoke: Palgrave Macmillan, pp.49-59.

Cantle, T. (2001) Community cohesion: a report of the Independent Review Team, London: Home Office.

Centre for Jewish-Arab Education (2015) Our schools [online]. Available at: https://www.handinhandk12.org/inform/our-schools (Accessed: 22 July 2015).

Charalambous, P., Charalambous, C. and Zembylas, M. (2014) 'Old and new policies in dialogue: Greek-Cypriot teachers’ interpretations of a peace-related initiative through existing policy discourses’, British Educational Research Journal, 40(1), pp.79-101.

Chisholm, L. and Sujee, M. (2006) 'Tracking racial desegregation in South African schools', Journal of Education, 40, pp.141-159.

CIA (2016) Country Profile: Macedonia [online]. Available at: https://www.cia.gov/library/publications/the-world-factbook/geos/mk.html (Accessed: 3 September 2016).

Connolly, P., Purvis, D. and O’Grady, P.J. (2013) Advancing shared education: report of the Ministerial Advisory Group. Belfast: Queen’s University.

DENI (2014) Minister launches call for applications from schools for shared education signature project [online]. Available at: http://www.northernireland.gov.uk/news-de-011214ministers-launch-call (Accessed 24 July). 
DENI (2015) Enrolments by school management type: 2000/01-2014/5. Bangor: DENI.

Donnelly, C. (2004) 'Constructing the ethos of tolerance and respect in an integrated school: the role of teachers', British Educational Research Journal, 30(2), pp.263-278.

Donnelly, C. (2008) 'The integrated school in a conflict society: a comparative analysis of two integrated primary schools in Northern Ireland', Cambridge Journal of Education, 38(2), pp.187-198.

Donnelly, C. and Hughes, J. (2006) 'Contact, culture and context: evidence from mixed faith schools in Northern Ireland and Israel', Comparative Education, 42(4), pp.493-516.

Duffy, G. and Gallagher, T. (2016) 'Shared Education in contested spaces: How collaborative networks improve communities and schools', Journal of Educational Change. Advance online publication. doi:10.1007/s10833-016-9279-3.

Duffy, G. and Gallagher, T (2014) 'Sustaining school partnerships: the context of crosssectoral collaboration between schools in a separate education system in Northern Ireland', Review of Education, 2(2), pp.189-210.

ETUCE (2015) ETUCE facilitates historic agreement between all Cypriot Teacher Unions [online]. Belgium: ETUCE. Available at: https://www.csee-etuce.org/en/news/archive/555etuce-facilitates-historic-agreement-between-all-cypriot-teacher-unions (Accessed 3 September 2016).

ETUCE (2016) Cyprus: Conference on the role of education in developing peace culture [online]. Belgium: ETUCE. Available at: https://www.csee-etuce.org/en/news/archive/1318cyprus-conference-on-the-role-of-education-in-developing-peace-culture (Accessed 3 September 2016).

Europa Publications (2003) ‘Cyprus’. The Europa World Yearbook: Volume I. London: Taylor and Francis.

FGS McClure Watters (2014) Evaluation of the Sharing Education Programme: Programme Level Summative Evaluation Report (Year 1 - 3) - Final Report [online]. Belfast: FGS McClure Watters. Available at: 
http://www.sepni.org/resources/6287/6428_6287_77_Evaluation_of_the_Sharing_Education _Programme.pdf (Accessed 3 September 2016).

Flint, J. (2007) 'Faith schools, multiculturalism and community cohesion: Muslim and Roman Catholic state schools in England and Scotland', Policy and Politics, 35(2), pp.251268.

Foster, P. (2016) Hopes rise for deal to end 40-year frozen conflict in Cyprus [online]. London: The Telegraph. Available at: http://www.telegraph.co.uk/news/2016/08/21/hopesrise-for-deal-to-end-40-year-frozen-conflict-in-cyprus/ (Accessed 4 September 2016).

Gallagher, T. (2004) Education in divided societies. Basingstoke: Palgrave Macmillan.

Gallagher, T. (2016) 'Shared education in Northern Ireland: school collaboration in divided societies', Oxford Review of Education, 42(3), pp.362-375.

Gallagher, T., Stewart, A., Walker, R., Baker, M. and Lockhart, J. (2010) 'Sharing education through schools working together', Shared Space, 10, pp.65-73.Grace, G. (2012) 'Faith schools: democracy, human rights and social cohesion', Policy Futures in Education, 10(5), pp.500-506.

Granovetter, M. S. (1973) 'The strength of weak ties’, American Journal of Sociology, 78(6), pp.1360-1380.

The Guardian (2015) Violence between Macedonia police and 'terrorists' increases scrutiny of PM. London: The Guardian [online]. Available at: https://www.theguardian.com/world/2015/may/11/macedonia-violence-nikola-gruevskigovernment (Accessed: 4 September 2016).

Hajisoteriou, C., Neophytou, L. and Angelides, P. (2012) 'Intercultural dimensions in the (new) curriculum of Cyprus: the way forward', The Curriculum Journal, 23(3), pp.387-405.

Halstead, J.M. and McLaughlin, T. (2005) ‘Are faith schools divisive?’, in Gardner, R., Cairns, J. and Lawton, D. (eds.) Faith schools: consensus or conflict? RoutledgeFalmer, pp.61-73. 
Hayes, B.C., McAllister, I. and Dowds, L. (2007) 'Integrated education, intergroup relations, and political identities in Northern Ireland', Social Problems, 54(4), pp.454-482.

Hayes, B.C., McAllister, I. and Dowds, L. (2013) 'Integrated schooling and religious tolerance in Northern Ireland', Journal of Contemporary Religion, 28(1), pp.67-78.

Hromadžić, A (2008) 'Discourses of integration and practices of reunification at the Mostar Gymnasium, Bosnia and Herzegovina’, Comparative Education Review, 52(4), pp.541-563.

Hughes, J. (2011) 'Are separate schools divisive? A case study from Northern Ireland', British Educational Research Journal, 37(5), pp.829-850.

Hughes, J. (2014) 'Contact and context: sharing education and building relationships in a divided society', Research Papers in Education, 29(2), pp.193-210.

Hughes, J. and Loader, R. (2015). “"Plugging the gap”: shared education and the promotion of community relations through schools in Northern Ireland', British Educational Research Journal, 41(6), pp.1142-1155.Hughes, J., Donnelly, C., Hewstone, M., Gallagher, T. and Carlisle, K. (2010) School partnerships and reconciliation: an evaluation of school collaboration in Northern Ireland. Belfast: Queen’s University.

Hughes, J., Leitch, R. and Banker, M. (2011) UNICEF consultation in relation to ECD/Education Programme 'Enhancing inter-ethnic community dialogue and collaboration project' report of workshop to develop a programme for implementation. Belfast: Queen's University.

Hughes, J., Lolliot, S., Hewstone, M., Schmid, K. and Carlisle, K. (2012) 'Sharing classes between separate schools: a mechanism for improving inter-group relations in Northern Ireland?’ Policy Futures in Education, 10(5), pp.528-539.

Hughes, J., Hewstone, M., Campbell, A., Lolliot, S. and Gallagher, T. (2013) 'Inter-group contact at school and social attitudes: evidence from Northern Ireland', Oxford Review of Education, 39(6), pp.761-779. 
Ioannou, M., Filippou, G., Lordos, A. (2015) 'The Cyprus SCORE: finding new ways to resolve a frozen conflict'. In SCORE, Predicting peace: The social cohesion and reconciliation index as a tool for conflict transformation ( $2^{\text {nd }}$ edition). Cyprus: United National Development Programme, pp.98-141.

Independent Balkan News Agency (2015) Greek Cypriot and Turkish Cypriot education unions send joint message on World Teachers’ Day [online]. Greece: Independent Balkan News Agency. Available at: http://www.balkaneu.com/greek-cypriot-turkish-cyprioteducation-unions-send-joint-message-world-teachers-day/ (Accessed 3 September 2016).

Johansen, H. and O'Neill, M. (2012) 'Ethnicity vs. citizenship in the workplace context: a case study of Macedonia’, Journal of Balkan and Near Eastern Studies, 14(1), pp.93-111.

Johnson, L.S. (2007) 'Moving from piecemeal to systemic approaches to peace education in divided societies: comparative efforts in Northern Ireland and Cyprus', in Bekerman, Z. and McGlynn, C. (eds.) Addressing ethnic conflict through peace education, Basingstoke: Palgrave Macmillan, pp.21-33.

Kades, A. (2016) Boost for bicommunal school ties [online]. Nicosia: Cyprus Mail. Available at: http://cyprus-mail.com/2016/05/15/boost-bicommunal-school-ties/ (Accessed 3 September 2016).

Kaymak, E. (2009) 'The Development of Turkish Cypriot Politics'. In J. Ker-Lindsay and H. Faustman (eds.) The Government and Politics of Cyprus. Bern: Peter Lang, pp.231-256.

Knox, C. (2010) Sharing Education Programme: views from the white board. Jordanstown: Atlantic Philanthropies.

Knox, C. (2013) 'Shared education: a case study in policy advocacy'. Paper presented at the Conference on the Impact and Potential of Shared Education, Queen’s University, Belfast, 26-27 June 2013. Available at: http://www.schoolsworkingtogether.co.uk/documents/ConferenceJune13/Colin\%20Knox.pdf (Accessed: 3 September 2016). 
Koneska, C. (2012) 'Vetoes, ethnic bidding, decentralisation: post-conflict education in Macedonia', Journal on Ethnopolitics and Minority Issues in Europe, 11(4), pp.28-50.

Koppa, M.-E. (2001) 'Ethnic Albanians in the former Yugoslav republic of Macedonia: between nationality and citizenship', Nationalism and Ethnic Politics, 7(4), pp.37-65.

Loader, R. (2015) Shared education in Northern Ireland: a qualitative study of intergroup contact. Unpublished PhD thesis. Queen’s University Belfast.

Loader, R. and Hughes, J. (2016) 'Joining together or pushing apart? Building relationships and exploring difference through shared education in Northern Ireland', Cambridge Journal of Education. Advance online publication. doi: 10.1080/0305764X.2015.1125448.

Loizides, N. (2011) 'Contested migration and settler politics in Cyprus’, Political Geography, 30(7), pp.391-401.

Lyon, A. (2013) 'Decentralisation and the provision of primary and secondary education in the Former Yugoslav Republic of Macedonia', International Journal on Minority and Group Rights, 20(4) pp.491-516.

Mavromatidis, F. (2010) 'The role of the European Union in the name dispute between Greece and FYR Macedonia’, Journal of Contemporary European Studies, 18(1), pp.47-62. 47-62.

Marusic, S.J. (2011) Macedonia-Greece name dispute: What's in a name? [online]. Skopje: Balkan Insight. Available at: http://www.balkaninsight.com/en/article/background-what-s-ina-name (Accessed 4 October 2016). Meredith, R. (2016) Ceremony to mark opening of NI's newest integrated school [online]. Belfast: BBC News. Available at: http://www.bbc.co.uk/news/uk-northern-ireland-37512515 (Accessed 4 October 2016).

Ministry of Education and Culture (Cyprus) (2016) Department of Primary Education [online]. Nicosia: Ministry of Education and Culture. Available at: http://www.moec.gov.cy/dde/en/ (Accessed 4 September 2016). 
Ministry of Education and Science (Macedonia) (2010) Steps towards integrated education in the educational system of the Republic of Macedonia. Skopje: MoES.

McGlynn, C. and Bekerman, Z. (2007) 'The management of pupil difference in CatholicProtestant and Palestinian-Jewish integrated education in Northern Ireland and Israel', Compare, 37(5), pp.689-703.

McGlynn, C., Niens, U., Cairns, E. and Hewstone, M. (2004) 'Moving out of conflict: the contribution of integrated schools in Northern Ireland to identity, attitudes, forgiveness, and reconciliation', Journal of Peace Education, 1(2), pp.147-63.

McGlynn, C. (2007) 'Rhetoric and reality: are integrated schools in Northern Ireland really making a difference?' Irish Educational Studies, 26(3), pp.271-287.

Montgomery, A., Fraser, G., McGlynn, C., Smith, A. and Gallagher, T. (2003) Integrated education in Northern Ireland: participation, profile and performance. Coleraine: University of Ulster.

Murchan, D., Shiel, G. and Mickovska, G. (2012) 'An education system in transition: assessment and examinations in the Republic of Macedonia', Assessment in Education: Principles, Policy and Practice, 19(4), pp.487-502.Northern Ireland Executive (2011) Programme for Government 2011-15. Belfast: Office of the First Minister and Deputy First Minister.

Northern Ireland Council for Integrated Education (2016) What is integrated education? [online]. Belfast: NICIE. Available at: http://www.nicie.org/about-us/integratededucation/what-is-integrated-education/ (Accessed: 4 October 2016).

Oztas Tum, D., Kunt, N. and Kunt, M. (2016) 'Language learning in conflictual contexts: a study of Turkish Cypriot adolescents learning Greek in Cyprus’, Language, Culture and Curriculum, 29(2), pp.207-224.

Papadakis, Y. (2008) 'Narrative, memory and history education: a comparison of Greek Cypriot and Turkish Cypriot schoolbooks on the "History of Cyprus"', History and Memory, 20(2), pp.128-148. 
Pettigrew, T.F. and Tropp, L.R. (2006) 'A meta-analytic test of intergroup contact theory’, Journal of Personality and Social Psychology, 90(5), pp.751-783.

Pettigrew, T.F. and Tropp, L.R. (2008) 'How does intergroup contact reduce prejudice? Meta-analytic tests of three mediators', European Journal of Social Psychology, 38(6), pp.922-934.

Philippou, S. (2007) 'Policy, curriculum and the struggle for change in Cyprus: the case of the European dimension in education', International Studies in Sociology of Education, 17(3), pp.249-274.

Phillips, D. and Ochs, K. (2003) 'Processes of policy borrowing in education: some explanatory and analytical devices’, Comparative Education, 39(4), pp.451-461.

Reka, A. (2008) 'The Ohrid Agreement: the travails of inter-ethnic relations in Macedonia,' Human Rights Review, 9(1), pp.55-69.

Richardson, N. (2011) 'Evaluating the Northern Ireland experience’, in Richardson, N. and Gallagher, T. (eds.) Education for diversity and mutual understanding: the experience of Northern Ireland. Oxford: Peter Lang., pp.331-351.

Shared Education Act (Northern Ireland) 2016, c.20. Available at: http://www.legislation.gov.uk/nia/2016/20/pdfs/nia_20160020_en.pdf?section-4-2-d.

Shaw, M. (2014) 'The Cyprus game: crossing the boundaries in a divided island', Globalisation, Societies and Education, 12(2), pp.262-274.

Silman, F. and Caglar, M. (2010) 'A comparative overview of citizenship education in Cyprus', International Review of Education, 56(5-6), pp.671-682.Smith, A. (2001) 'Religious segregation and the emergence of integrated schools in Northern Ireland', Oxford Review of Education, 27(4), pp.559-575.

Soudien, C. (2004). 'Constituting the class: an analysis of the process of "integration” in South African schools', in Chisholm, L. (ed.) Education and social change in South Africa. Pretoria, HSRC Press. 
Soudien, C. (2007) 'The asymmetrics of contact: an assessment of 30 years of school integration in South Africa', Race, Ethnicity and Education, 10(4), pp.439-456.

Steiner-Khamsi, G. (2014) 'Cross-national policy borrowing: understanding reception and translation', Asia Pacific Journal of Education, 34(2), pp.153-167.Stringer, M., Wilson, R., Irwing, P., Giles, M., McClenahan, C. and Curtis, L. (2000) The impact of schooling on the social attitudes of children. Belfast: Integrated Education Fund.

Stringer, M., Irwing, P., Giles, M., McClenahan, C., Wilson, R. and Hunter, J.A. (2009) 'Intergroup contact, friendship quality and political attitudes in integrated and segregated schools in Northern Ireland', British Journal of Educational Psychology, 79(2), pp.239-257.

Tolomelli, A. (2015) “"Two schools under one roof”: the role of education in the reconciliation process in Bosnia and Herzegovina', Ricerche di Pedagogia e Didattica Journal of Theories and Research in Education ${ }_{2}$ 10(1), pp.89-108.

Tugwell, P and Georgio, G. (2016) Cyprus Unification Deal May Happen in 2016, Government Says [online]. Available at: http://www.bloomberg.com/news/articles/2016-0608/cyprus-reunification-deal-could-happen-in-2016-government-says (Accessed 4 September 2016).

United Nations Security Council (2016) Report of the Secretary-General on the United Nations operation in Cyprus [online]. Available at: http://www.un.org/en/ga/search/view_doc.asp?symbol=S/2016/11 (Accessed: 4 September 2016).

Vandeyar, S. (2010) 'Responses of South African teachers to the challenge of school integration', South African Journal of Education, 30(3), pp.343-359.

Vandeyar, S. and Esakov, H. (2007) 'Colour coded: how well do students of different race groups interact in South African schools?', in Bekerman, Z. and McGlynn, C. (eds.) Addressing ethnic conflict through peace education, Basingstoke: Palgrave Macmillan, pp.63-75. 
Vandeyar, S. and Killen, R. (2006) 'Teacher-student interactions in desegregated classrooms in South Africa', International Journal of Educational Development, 26(4), pp.382-393.

Weinstein, H.M., Freedman, S.W. and Hughson, H. (2007) School voices: challenges facing education systems after identity-based conflicts, Education, Citizenship, and Social Justice, 2(1), pp.41-71.

Wenger, E. (1998) Communities of practice: learning, meaning, and identity. Cambridge: Cambridge University Press.

Wenger, E. (2000) 'Communities of practice and social learning systems', Organization, 7(2), pp.225-246.

Zembylas, M. (2010) 'Negotiating co-existence in divided societies: teachers, students and parents' perspectives at a shared school in Cyprus', Research Papers in Education, 25(4), pp.433-455.

Zembylas, M., Charalambous, C. Charalambous, P. and Kendeou, P. (2011a) 'Promoting peaceful coexistence in conflict-ridden Cyprus: teachers' difficulties and emotions towards a new policy initiative’, Teaching and Teacher Education, 27(2), pp.332-341.

Zembylas, M., Charalambous, P. and Charalambous, C. (2011b) 'Teachers' emerging stances and repertoires towards reconciliation: potential and challenges in Greek-Cypriot education', Journal of Peace Education, 8(1), pp.19-36.

Zembylas, M., Bekerman, Z., McGlynn, C. and Ferreira, A. (2009) 'Teacher’s understanding of reconciliation and inclusion in mixed schools in four troubled societies', Research in Comparative and International Education, 4(4), pp.406-422. 